\title{
Black Carbon and West African Monsoon precipitation: observations and simulations
}

\author{
J. Huang ${ }^{1}$, A. Adams ${ }^{1}$, C. Wang ${ }^{2}$, and C. Zhang ${ }^{1}$ \\ ${ }^{1}$ Rosenstiel School of Marine and Atmospheric Science, University of Miami, Miami, FL 33149, USA \\ ${ }^{2}$ Dept. of Earth, Atmospheric, and Planetary Sciences, Massachusetts Inst. of Technology, Cambridge, MA 02139-4307, USA
}

Received: 30 March 2009 - Revised: 15 July 2009 - Accepted: 24 October 2009 - Published: 5 November 2009

\begin{abstract}
We have recently investigated large-scale covariability between aerosol and precipitation and other meteorological variables in the West African Monsoon (WAM) region using long term satellite observations and reanalysis data. In this study we compared the observational results to a global model simulation including only direct radiative forcing of black carbon (BC). From both observations and model simulations we found that in boreal cold seasons anomalously high African aerosols are associated with significant reductions in cloud amount, cloud top height, and surface precipitation. These results suggest that the observed precipitation reduction in the WAM region is caused by radiative effect of BC. The result also suggests that the BC effect on precipitation is nonlinear.
\end{abstract}

Keywords. Atmospheric composition and structure (Aerosols and particles) - Meteorology and atmospheric dynamics (Precipitation; Radiative processes)

\section{Introduction}

By absorbing and scattering solar radiation, aerosols can affect precipitation through its radiative effect on surface and atmospheric heat budgets, which modulate the large scale circulation (e.g. Chung and Seinfeld, 2005; Haywood and Boucher, 2000). Meanwhile as cloud condensation nuclei $(\mathrm{CCN})$ or ice nuclei (IN), aerosols can also produce various non-exclusive effects on cloud microphysics, such as the cloud albedo effect, cloud lifetime effect, semi-direct effect, glaciation effect and thermodynamic effect (e.g., Ramanathan et al., 2001; Lohmann and Feichter, 2005; Denman et al., 2007, and therein). Evidence also suggests that

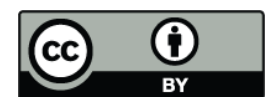

Correspondence to: J. Huang (jhuang@rsmas.miami.edu) aerosols can have remote impact on precipitation by altering the atmospheric large-scale circulation (e.g. Rotstayn et al., 2007; Wang, 2004, 2007). Model simulations demonstrated that radiative forcing of anthropogenic aerosols from present-day and pre-industrial conditions have significant influence on upper tropospheric clouds and water vapor (Liu et al., 2009), and exert different perturbations in the radiative energy budget of the global climate system (Schulz et al., 2006). Lau et al. (2008) explicitly explained the possible radiative, miscrophysical and dynamical mechanisms in the aerosol-monsoon interaction. However, as stated in the fourth climate assessment report of Intergovernmental Panel on Climate Change (IPCC), the sign of the global change in precipitation due to aerosols is not yet known (Denman et al., 2007). Due to the natural variability and complexity of many processes involved (Menon, 2004), observational and modeling studies on aerosol-cloud-precipitation interaction do not always produce consistent results (e.g. Takemura et al., 2005; Tao et al., 2007). Few attempts have been made to compare large-scale observed and simulated aerosol-precipitation relationships. Such comparisons are needed for evaluating the performance of the models and thus to build our confidence in using these tools to specify and quantify certain physical mechanisms that would be otherwise difficult to reveal with observations alone.

The West African Monsoon (WAM) region provides an ideal natural test bed for studying aerosol effects on precipitation. It is so because aerosols over this region are among the greatest and most persistent on Earth with distinct seasonal variability: mineral dust from North African sources in May-August, biomass burning smokes from southern Africa in July-September, and their mixture in November-February due to persistent year-long dust emission from some North African sources and biomass burning in Sahel region (e.g. Carlson and Prospero, 1972; Prospero and Lamb, 2003; Dwyer et al., 2000; Duncan et al., 2003; Ito and Penner, 2005; Huang et al., 2009d). 
Table 1. Datasets and their regional-averaged mean and standard deviation in the WAM region.

\begin{tabular}{|c|c|c|c|c|c|c|c|}
\hline & Source & Variable & $\begin{array}{l}\text { Resolution } \\
\text { (latitude } \times \\
\text { longitude) }\end{array}$ & Unit & $\begin{array}{r}\text { Annual } \\
\text { mean }\end{array}$ & $\begin{array}{r}\text { Annual mean } \\
\text { standard } \\
\text { deviation }\end{array}$ & $\begin{array}{r}\text { Changes in normalized } \\
\text { anomalies over } \\
{[0-10 \mathrm{~N}, 17.5 \mathrm{~W}-10 \mathrm{E}]}\end{array}$ \\
\hline \multirow{10}{*}{ Observation } & TOMS & Aerosol index & $1^{\circ} \times 1.25^{\circ}$ & & 1.17 & 0.277 & 1.54 \\
\hline & GPCP & Precipitation & $2.5^{\circ} \times 2.5^{\circ}$ & $\mathrm{mm} / \mathrm{d}$ & 3.03 & 0.885 & -0.942 \\
\hline & \multirow{4}{*}{ ISCCP } & Cloud amount & \multirow{4}{*}{$2.5^{\circ} \times 2.5^{\circ}$} & $\%$ & 58.5 & 6.77 & -0.300 \\
\hline & & Cloud top pressure & & $\mathrm{mb}$ & 541 & 63.8 & 0.462 \\
\hline & & Cloud top temperature & & K & 264 & 7.09 & 0.397 \\
\hline & & Cloud water path & & $\mathrm{g} / \mathrm{m}^{2}$ & 54.3 & 12.6 & -0.442 \\
\hline & NOAA satellites & Outgoing longwave radiation (OLR) & $2.5^{\circ} \times 2.5^{\circ}$ & $\mathrm{W} / \mathrm{m}^{2}$ & 250 & 8.53 & 0.216 \\
\hline & \multirow[t]{3}{*}{$\begin{array}{l}\text { NCEP-DOE re- } \\
\text { analysis } 2\end{array}$} & $U$ wind $(850 \mathrm{hPa})$ & \multirow{3}{*}{$2.5^{\circ} \times 2.5^{\circ}$} & $\mathrm{m} / \mathrm{s}$ & -2.80 & 1.74 & -0.0017 \\
\hline & & $V$ wind $(850 \mathrm{hPa})$ & & $\mathrm{m} / \mathrm{s}$ & -0.192 & 1.09 & 0.144 \\
\hline & & Omega $(850 \mathrm{hPa})$ & & $\mathrm{Pa} / \mathrm{s}$ & -0.0175 & 0.0291 & 0.0327 \\
\hline \multirow{8}{*}{ Simulation } & \multirow{8}{*}{$\begin{array}{l}\text { Air-sea coupled } \\
\text { GCM with black } \\
\text { carbon radiative } \\
\text { forcing }\end{array}$} & Black carbon & \multirow{8}{*}{$2.8^{\circ} \times 2.8^{\circ}$} & $\mathrm{kg} / \mathrm{m}^{2}$ & 1.88 & 0.301 & 1.212 \\
\hline & & Precipitation & & $\mathrm{mm} / \mathrm{d}$ & 2.95 & 1.14 & -0.829 \\
\hline & & $U$ wind $(850 \mathrm{hPa})$ & & $\mathrm{m} / \mathrm{s}$ & -0.138 & 0.895 & -0.272 \\
\hline & & $V$ wind $(850 \mathrm{hPa})$ & & $\mathrm{m} / \mathrm{s}$ & 2.84 & 0.719 & 0.194 \\
\hline & & Omega $(850 \mathrm{hPa})$ & & $\mathrm{Pa} / \mathrm{s}$ & -0.0186 & 0.0154 & 0.143 \\
\hline & & Cloud amount & & $\%$ & 56.8 & 8.96 & -0.607 \\
\hline & & OLR & & $\mathrm{W} / \mathrm{m}^{2}$ & 268 & 9.88 & 0.780 \\
\hline & & Water vapor & & $\mathrm{g} / \mathrm{m}^{2}$ & 35.6 & 2.34 & -0.933 \\
\hline
\end{tabular}

Using satellite data we have demonstrated that a high concentration of aerosols can induce significant precipitation reduction in the WAM region along the coast of the Gulf of Guinea, particularly in the boreal late autumn and winter (Huang et al., 2009a, b). The mechanism for this reduction is, however, unclear. In this study we aim to explore possible mechanisms by comparing observed and model simulated aerosol-induced changes in various meteorological variables. We will first describe observational data and data processing in Sect. 2, followed by model description in Sect. 3. Then we will present results in Sect. 4. Section 5 gives a summary and discussions.

\section{Observational data and data processing}

Unless otherwise noted, our observational data analysis covers the period of 1979-2000 during which Total Ozone Mapping Spectrometer Aerosol Index (TOMS AI), the main aerosol data in this study, is available. Monthly mean TOMS AI, the Global Precipitation Climatology Project (GPCP) precipitation data, the NOAA interpolated outgoing longwave radiation (OLR) data, and the NCEP-DOE reanalysis 2 wind data were used for this period. For statistical relations of aerosol to cloud we use a shorter period of 1983-2000 for which the ISCCP cloud data are available. The purpose of this analysis period is to examine changes in cloud amount that accompany the changes in precipitation under aerosol effects. A summary of all the variables from observations and model simulations is given in Table 1 with their climatological mean and standard deviation.

TOMS AI (Herman et al., 1997; Torres et al., 1998) is sensitive to ultraviolet-absorbing mineral dust and biomass burning smoke. In this study, the latest version- 8 monthly TOMS AI was used; it combines data from Nimbus-7 (N7, November 1978 to April 1993) and Earth Probe (EP, August 1996 to December 2000). The spatial resolution is $1^{\circ}$ latitude by $1.25^{\circ}$ longitude. The use of TOMS AI is justified by the fact that in the WAM region dust and smoke are the two major UV absorbing aerosol types whose variability can be sensitively traced by TOMS AI without complications from nonabsorbing aerosols such as sea salt and industrial pollution. The dust variability observed by TOMS AI was also verified by the long term dust ground record in Barbados (e.g. Ginoux et al., 2004). The GPCP precipitation data are available as a merged product consisting of low-orbit satellite microwave data (after mid 1987), geosynchronous-orbit satellite infrared data, and surface rain gauge observations (Huffman et al., 1997; Adler et al., 2003; Yin et al., 2004). The spatial resolution is $2.5^{\circ}$ latitude by $2.5^{\circ}$ longitude. The ISCCP D 2 data, available from 1983 to 2000 (Rossow and Schiffer, 1991, 1999), categorize low, medium and high clouds by their top. The data also provide cloud top pressure, cloud top temperature, and cloud water path that are of interest to this study. The OLR data from NOAA polar-orbiting satellites are often used to identify areas of tropical deep convection and to evaluate the radiation budget of the Earth (Gruber and 
(a)

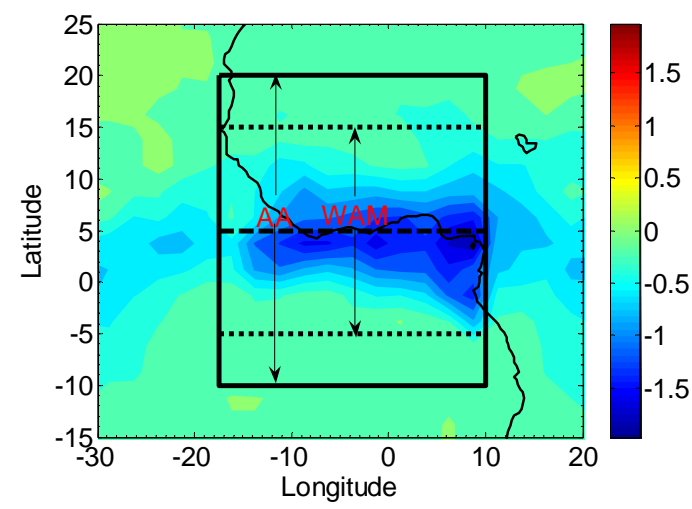

(c)

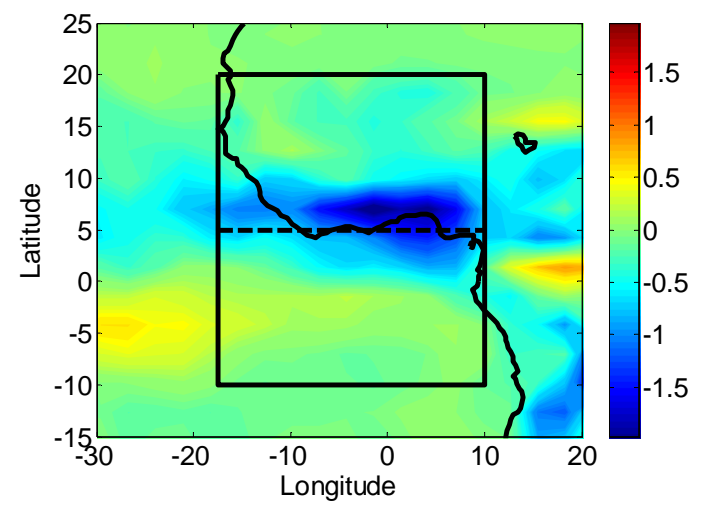

(b)

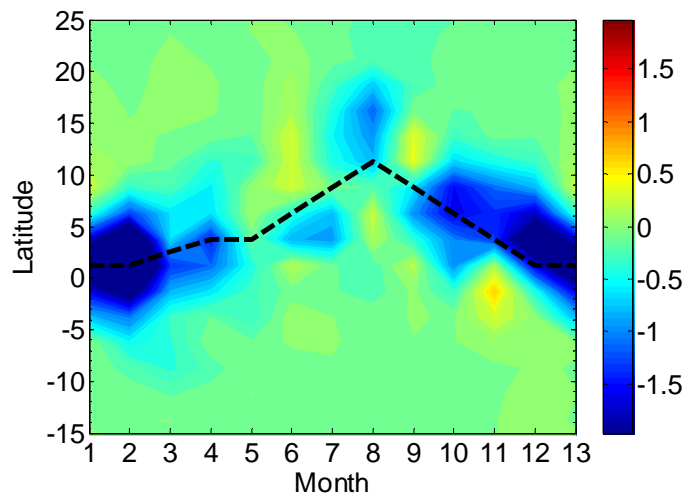

(d)

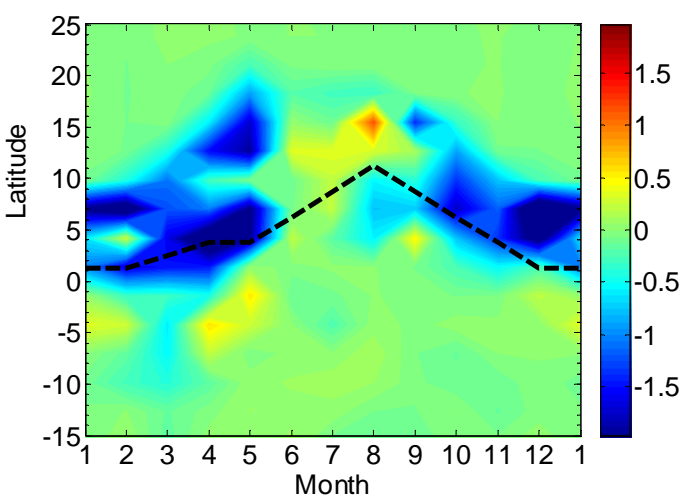

Fig. 1. The changes in the observed precipitation between high and low aerosol tercile-months: (a) spatial pattern, and (b) seasonal variability (after Huang et al., 2009a). (c) and (d) are similar to (a) and (b) but for the simulated precipitation. The relatively larger aerosol domain (AA) and the precipitation (and other meteorological variables) domain (WAM) with their corresponding boundaries are marked in (a). The dashed lines mark the center of the mean West African Monsoon rain band.

Krueger, 1984; Liebmann and Smith, 1996). In the interpolated OLR data gaps were filled with temporal and spatial interpolation (Liebmann and Smith, 1996). The spatial resolution is $2.5^{\circ} \times 2.5^{\circ}$. For the primary data analysis period 1979-2000, we also use wind data from the NCEP-DOE Reanalysis 2 (Kanamitsu et al., 2002).

We adapted the same data processing method described in Huang et al. (2009a, c). An aerosol time series was derived from an African aerosol domain (AA domain), which is larger than the WAM domain for the time series of precipitation (Fig. 1). The seasonal cycle was first removed from both time series. We then identified El Niño-Southern Oscillation (ENSO), North Atlantic Oscillation (NAO), and Atlantic zonal and meridional sea surface temperature (SST) modes as known climate factors that modulate natural variability of aerosol and other meteorological variables (e.g. Prospero and Lamb, 2003; Chiapello et al., 2005; Washington and Todd, 2005; Washington et al., 2006).

Their corresponding representative indices, namely, the NINO3.0 index $\left(5^{\circ} \mathrm{S}-5^{\circ} \mathrm{N}, 90^{\circ} \mathrm{W}-150^{\circ} \mathrm{W}\right.$, Philander, 1990), the NAO index (Hurrell, 1995), the ATL3.0 index $\left(3^{\circ} \mathrm{S}-3^{\circ} \mathrm{N}, 20^{\circ} \mathrm{W}-0^{\circ}\right.$, Zebiak, 1993), and the TNA-TSA index (SST anomaly difference between $5^{\circ}-25^{\circ} \mathrm{N}, 55^{\circ}-15^{\circ} \mathrm{W}$ and $0^{\circ}-20^{\circ} \mathrm{S}, 30^{\circ} \mathrm{W}-10^{\circ} \mathrm{E}$, Servain, 1991), were used in a multi-variable regression technique to remove their coherent signals in both aerosol and precipitation time series. The residual aerosol and precipitation anomalies are not linearly explained by these known climate factors. We further normalized the anomalies using their interannual standard deviation of each calendar month averaged over the respective analysis domains. The statistical analysis is mainly conducted between the normalized anomalies of aerosols, precipitation and other variables. The spatial and temporal variability of the differences in these variables between the high and low aerosol scenarios will be presented to help interpret the observed aerosol-precipitation relationship.

\section{Model}

An interactive aerosol-climate model designed to simulate only the direct radiative effect of black carbon (BC) was 
developed based on the Community Climate Model version 3 (CCM3) of the National Center for Atmospheric Researches (Wang, 2004). The model has a horizontal resolution of $2.8^{\circ} \times 2.8^{\circ}$ degree and 18 vertical layers from the Earth's surface to $3 \mathrm{hPa}$. Processes that modulate the $3-\mathrm{D}$ distribution of $\mathrm{BC}$ include emissions, transport and mixing, dry deposition and gravitational sedimentation, and wet removal. The climate dynamics model calculates these processes utilizing the predicted winds, temperature, air density and pressure, cloud cover, and precipitation. The annual emissions from fossil fuel use and biomass burning were $\sim 8$ and $\sim 6 \mathrm{Tg} \mathrm{C}$, respectively. The inclusion of $\mathrm{BC}$ aerosols in the 18-band solar radiation module of CCM3 (Briegleb, 1992) was formulated following Kiehl and Briegleb (1993). The needed optical parameters of $\mathrm{BC}$ aerosols were derived based on the Mie scattering theory (Wang, 2004), specifically, the Model 1 of BC optical parameter set in Wang (2004) is used (Table 1 in Wang, 2004). The direct effect of $\mathrm{BC}$ on long-wave radiation was omitted, and so was the much more complicated and poorly-understood indirect radiative forcing of BC aerosols. Above calculations were processed at the same time step of the climate model to achieve a fully interactive coupling between the aerosol module and the CCM3 climate model. Two model runs coupled with a slab ocean model were conducted: a reference run without and a forcing run with the radiative effect of BC. Both runs last 60 years to reach a quasiequilibrium state. The last 20 years of model outputs were used in the analyses in this study. Details of the model and model configuration were given by Wang (2004). The direct radiative forcing of $\mathrm{BC}$ estimated by this model is within the range of previous works (see Table 2.5 in Forster et al., 2007). The remote impact of $\mathrm{BC}$ radiative forcing on precipitation was also suggested in different interactive BC-climate modeling efforts (e.g. Roberts and Jones, 2004; Chung and Seinfeld, 2005).

It should be emphasized that the model used does not include other aerosol types other than black carbon. We had chosen to compare our observational results to simulations of this model for two reasons: 1) Using long term satellite observations, we observed significant large-scale aerosolprecipitation covariability in the Pan-Atlantic region only in boreal cold seasons when biomass burning smokes are one of dominant aerosols in the troposphere. We did not observe such significant relationship in boreal summer when mineral dust is the sole predominant aerosol in the tropical Atlantic (Huang et al., 2009a, b, c). The logical thinking is that if aerosol effect is responsible for the observed relationship, it probably comes from BC. 2) An important conclusion from Rosenfeld et al. (2008) is that aerosol radiative and microphysical forcing may be dominant over different aerosol loadings: when aerosol optical depth is at its higher end, as in the WAM region, radiative forcing becomes more significant over microphysical effect. Additionally, the model simulations of aerosol microphysical effect still have large uncertainties. One often observes large difference between differ- ent model schemes. But aerosol radiative forcing is better understood and simulated after many years of profound studies. Thus we think it is a logical first step to pursue a comparison between observations and model simulations with only $\mathrm{BC}$ radiative effect over the WAM region.

To make the model results comparable to observational results, we applied the same data processing method to the model simulations except there is no need to remove effects from known climate factors (such as ENSO, NAO and NAV) because they were not reproduced by the model. The difference between the forcing and reference runs is also analyzed to isolate the $\mathrm{BC}$ radiative effect.

\section{Results}

\subsection{Aerosol and precipitation}

A large-scale reduction in precipitation in the WAM region associated with high concentration of African aerosols has been observed using satellite data (Huang et al., 2009a, b). This observation is compared to the model simulation from the forcing run in Fig. 1, which shows differences between composites of precipitation for months of high vs. low aerosol concentrations. The high and low months of aerosol concentration are defined as the top and bottom terciles of the monthly time series of aerosol normalized anomalies. The simulation agrees with the observation in that the most significant aerosol-induced reduction in precipitation occurs along the Guinea coast in boreal winter and spring. The model produced convective and large-scale precipitation. Only the changes in convective precipitation have the spatial and seasonal variability similar to the observed. This agreement between the observation and simulation signifies that if the observed reduction in precipitation is due to direct radiative forcing of aerosol, it is BC that suppresses isolated sub-grid precipitation processes. A possible reason for the resolvable large-scale precipitation not affected by the local BC radiative effect is that large-scale precipitation is more controlled by the large-scale circulation and less sensitive to local changes in radiative heating/cooling. Other associated meteorological responses to the $\mathrm{BC}$ radiative forcing are discussed in the following sections.

\subsection{Aerosol and cloud}

The aerosol-cloud interaction is highly uncertain due to the complexity of many microphysical processes involved. For example, known as cloud albedo effect and cloud lifetime effect, excessive aerosols may increase $\mathrm{CCN}$ numbers, decrease cloud particle size, thus enhance cloud albedo, lengthen the cloud lifetime and increase cloudiness (Twomey et al., 1978; Albrecht, 1989); on the other hand, known as semi-direct effect (Hansen et al., 1998), the extra solar absorption by excessive aerosols can potentially warm up the surrounding cloud, increase the evaporation rate of the cloud 
(a)

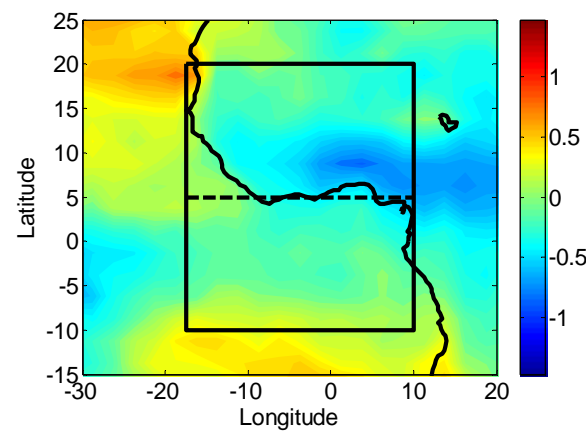

(C)

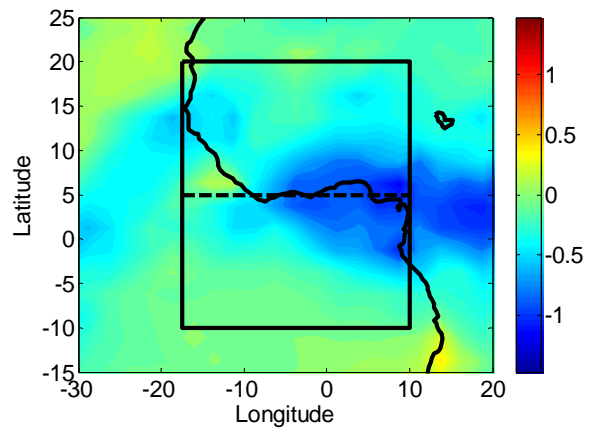

(e)

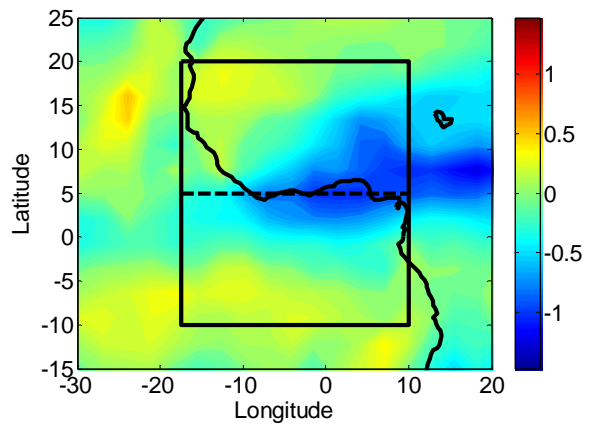

(g)

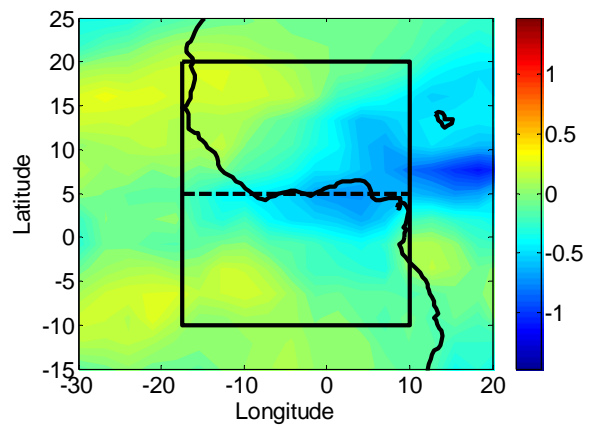

(b)

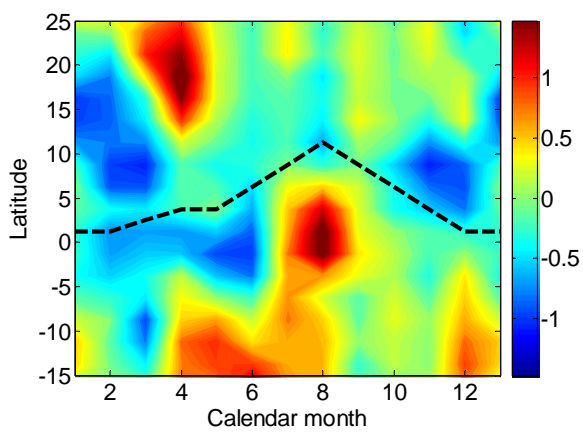

(d)

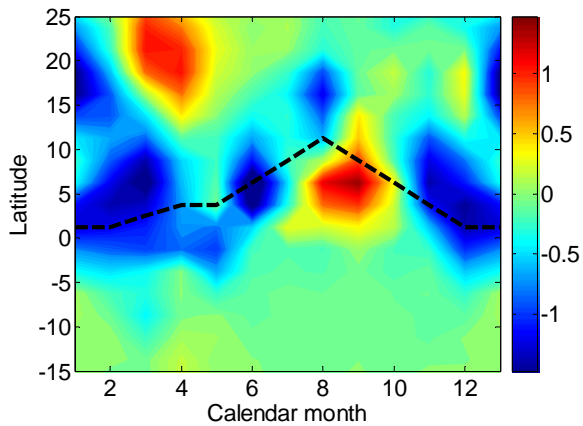

(f)

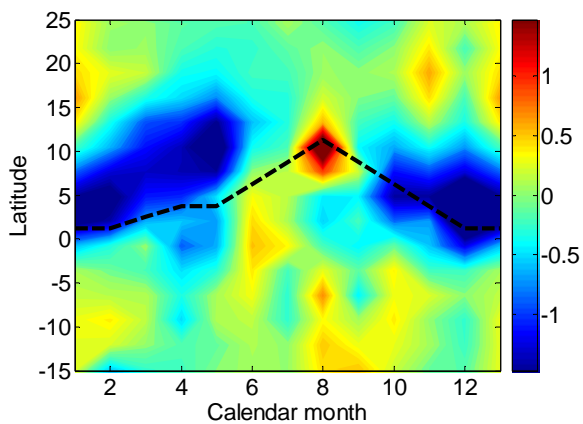

(h)

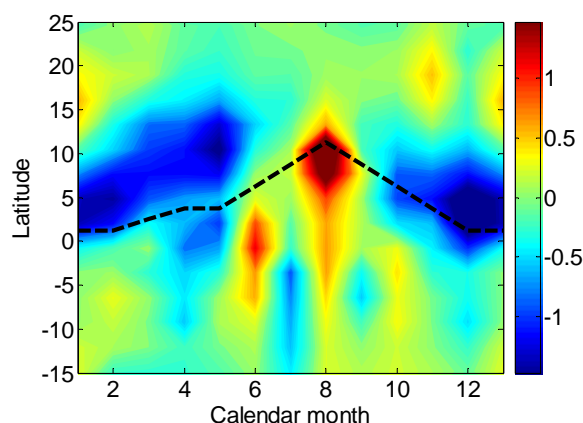

Fig. 2. The aerosol-induced changes in the normalized anomalies of the observed total cloud amount: (a) spatial pattern, and (b) seasonal variability. (c-d), (e-f) and ( $\mathbf{g - h})$ are the same to (a-b) but for the observed high cloud amount, the simulated total cloud amount and the simulated high cloud amount, respectively. The dashed lines mark the center of the mean West African Monsoon rain band. 
particles and reduce the cloud (Ackerman et al., 2000). Because of these aerosol effects, cloud can be either suppressed (e.g. Feingold et al., 2005, for smoke suppression of cloud in Amazonia) or invigorated (e.g. Kaufman et al., 2005; Koren et al., 2005, for aerosol invigoration of Atlantic convective cloud) or both (e.g. Koren et al., 2008, for smoke invigoration and inhibition over the Amazon). It would be interesting to see how cloud would vary in association with a reduction in precipitation in the WAM region due to high concentration of aerosol, such as that observed and simulated with BC radiative effect only (Fig. 1).

With a similar composite procedure applied to the ISSCP cloud data, we found a significant reduction in the total cloud amounts along the Guinea coast associated with anomalously high aerosol (Fig. 2a). Although suppression is also found in middle and low clouds, the most notable reduction is in the high cloud amount (Fig. 2b). Model simulations produced very similar results (Fig. 2c and d).

In addition to the reduction in the total cloud amount, aerosols also appear to decrease the cloud top altitude as measured by increases in cloud top pressure (Fig. 3a, b). It is clear that the observed reduction in precipitation is not associated with increases in clouds as expected if some of the cloud microphysical effects of aerosol are involved. This is consistent to the notion that the BC radiative effect (absorbing) tends to increase the atmospheric stability locally and thus weaken isolated sub-grid precipitation. This is also consistent to the suggestion purely from observations that the observed negatively correlated relationship between aerosol and precipitation in the WAM region cannot be explained by the washout effect (Huang et al., 2009a, b, c), evident from spatial and seasonal patterns and rain rate sensitivity of the observed aerosol effect, and its comparison to the model simulated washout effect. Consistently, the cloud water path, a variable indirectly indicating cloud depth, also decreases significantly as the aerosol concentration becomes anomalously high (Fig. 3c, d). Further evidence of cloud suppression is found in the enhanced outgoing longwave radiation (OLR) during high aerosol tercile months (Fig. 3e, f). Such results, once again, was reproduced by the model simulation (Fig. 3g, h). Therefore we are more confident that the aerosol-induced precipitation reduction is due to the suppression of precipitating clouds by aerosol direct radiative effects of BC.

To confirm the aerosol suppression of precipitation and cloud, we conducted a consistency check on changes in the wind fields. In the high aerosol tercile months, both observations and simulation show stronger divergence in the meridional wind field and weakened upward motions at the $850 \mathrm{hPa}$ level (not shown). These consistent responses in the wind fields from the reanalysis help rule out any remaining doubt that the observed aerosol-precipitation relationship might results from errors in satellite data retrievals.

To summarize the association of aerosol with the above mentioned meteorological variables, we conducted an additional correlation analysis between the AA-domain aver- aged aerosol normalized anomalies and the WAM-domain averaged normalized anomalies of other meteorological variables. We put the emphasis only on the boreal winter season when the most significant aerosol-cloud and aerosolprecipitation relationships are found.

Both observations and model simulations show significant (at the 99\% confidence level) negative correlations between aerosol and precipitation. The model output further verifies that such negative correlation is mainly from convective precipitation. Consistently, both observations and simulations also found significant (at the 99\% confidence level) negative correlation between aerosol and total or high cloud amount. Significant (at the 99\% confidence level) positive correlations also exist between aerosol and other cloud variables such as cloud top pressure, cloud top temperature, and OLR in observations. These significant correlations indicate that the composite differences in Figs. 1-3 are indeed statistically robust.

In addition to the correlations, we also calculated the changes in the normalized anomalies of each variable when aerosol (or BC in the simulation) normalized anomalies increases from low tercile months to high tercile months (last column in Table 1). By inversing the normalization procedure (see Sect. 2), one can quantitatively approximate the aerosol-attributed changes in these variables. For example, the difference in the observed precipitation between high and low aerosol tercile months is about $-0.942 \mathrm{~mm} / \mathrm{d}$, which is roughly $31 \%$ of the annual mean precipitation; in the model simulation, these two values are $-0.829 \mathrm{~mm} / \mathrm{d}$ and $28 \%$, respectively (see Table 1).

\subsection{Nonlinearity}

It is interesting to point out that the radiative effect of BC on precipitation may not be linear. If the $\mathrm{BC}$ radiative effect on precipitation is linear, then the reference run (without $\mathrm{BC}$ radiative effect) can be viewed as an extreme case asymptotically approached by the lower tercile of $\mathrm{BC}$ concentration in the forcing run as the $\mathrm{BC}$ concentration goes to zero. In this case, similar pattern of reduction should be expected, if with different (larger) amplitudes, from the precipitation composite difference between the forcing and reference runs. This is not the case. The precipitation is indeed reduced in the forcing run in comparison to the reference run (Fig. 4), but the pattern of the changes is quite different from what shown in Fig. 1. If the large-scale circulation responds linearly to the radiative forcing of $\mathrm{BC}$, then the nonlinearity may come from the way precipitation is controlled by the large-scale circulation. The possible nonlinear nature of the precipitation response to $\mathrm{BC}$ radiative forcing as simulated by the model extends globally. We compared the composite difference in precipitation between high and low tercile months in terms of the $\mathrm{BC}$ concentration in the forcing run (Fig. 5a) and the difference in precipitation between the forcing and reference runs (Fig. 5b). It is clear that in some regions, the difference 
(a)

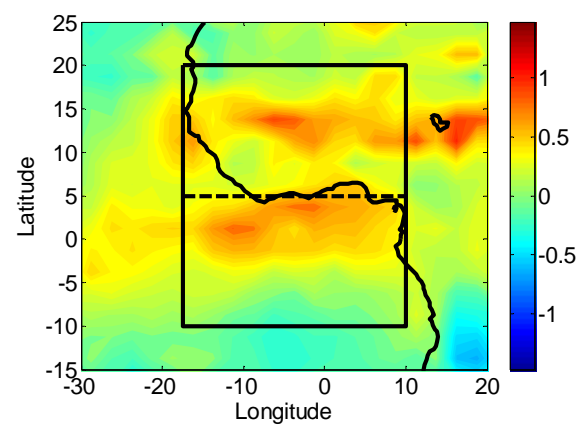

(c)

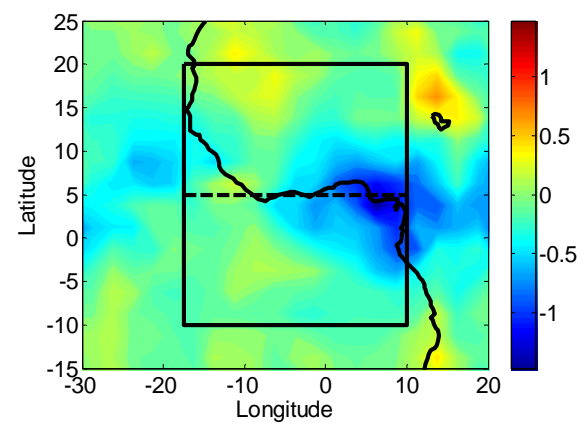

(e)

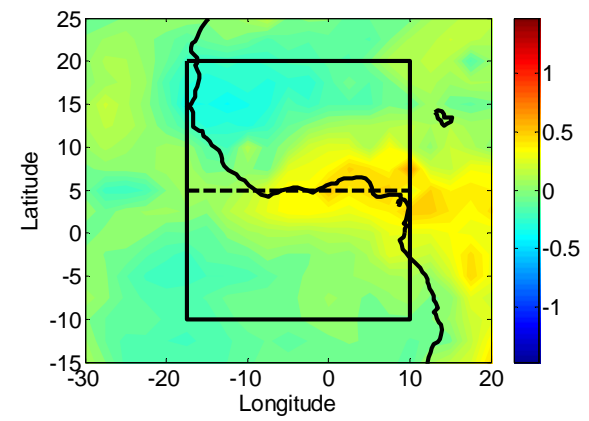

(g)

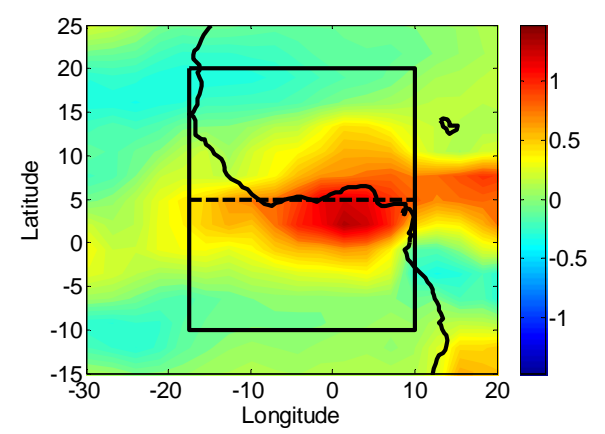

(b)

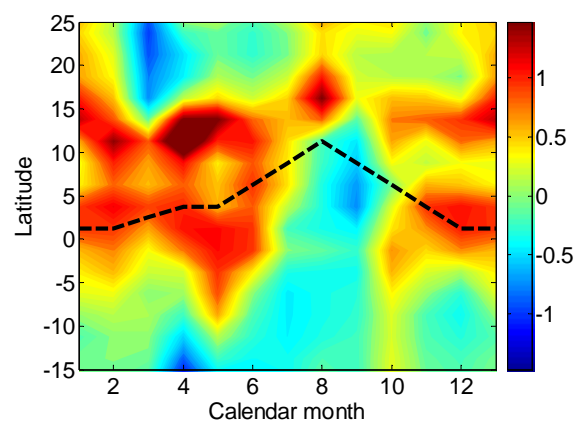

(d)

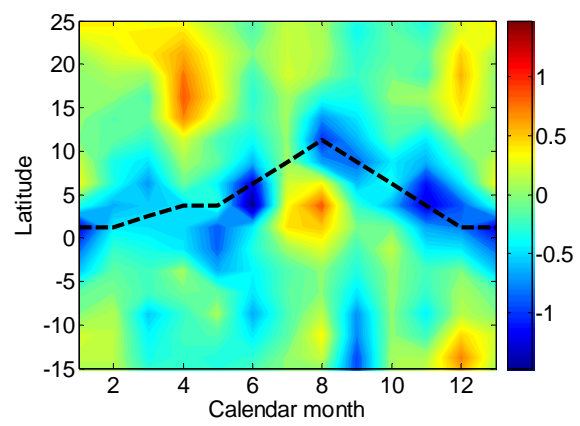

(f)

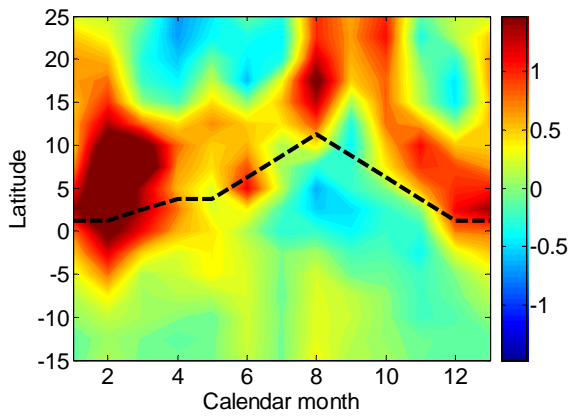

(h)

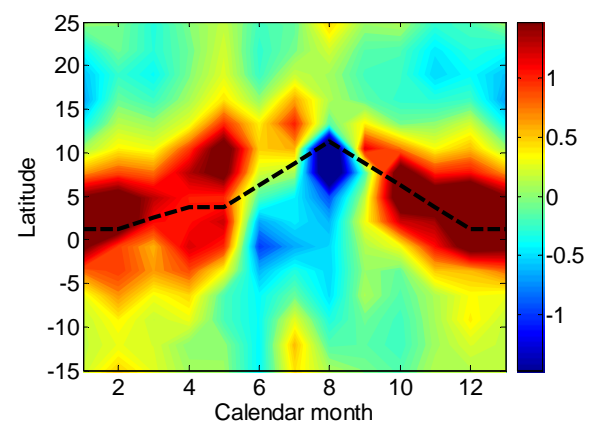

Fig. 3. Aerosol-induced changes in the spatial pattern (left column) and seasonal cycle (right) for the normalized anomalies of the observed cloud-top pressure (a and b), observed cloud water path (c and d), observed outgoing longwave radiation (OLR) (e and f), and simulated OLR $(\mathbf{g}$ and $\mathbf{h})$. The dashed lines mark the center of the mean West African Monsoon rain band. 
(a)

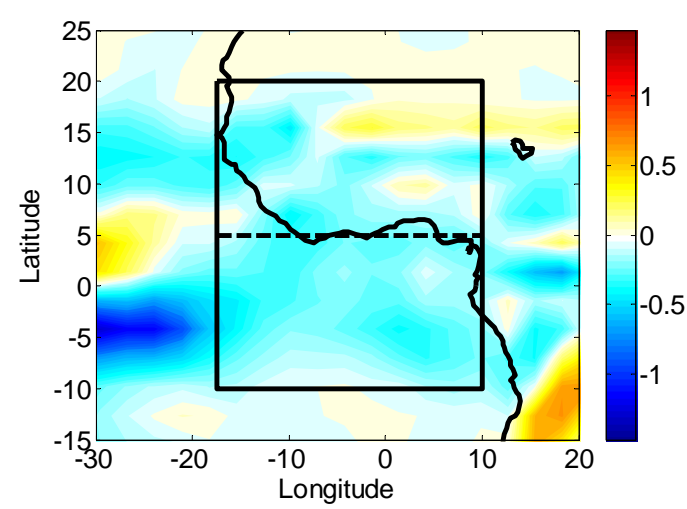

(b)

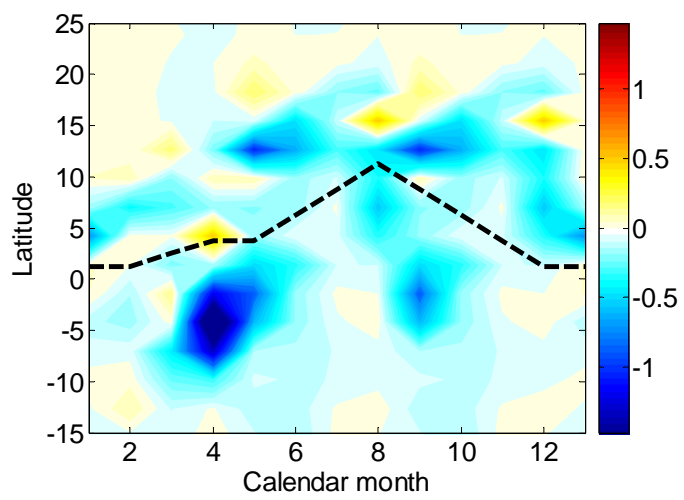

Fig. 4. The simulated precipitation difference between the $\mathrm{BC}$ radiative forcing run and the reference run in the WAM region: (a) spatial pattern; and (b) seasonal variability. The dashed lines mark the center of the mean West African Monsoon rain band.

(a)

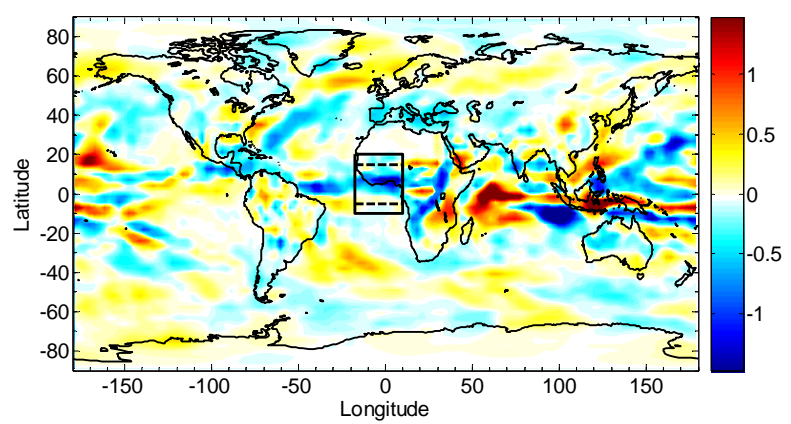

(b)

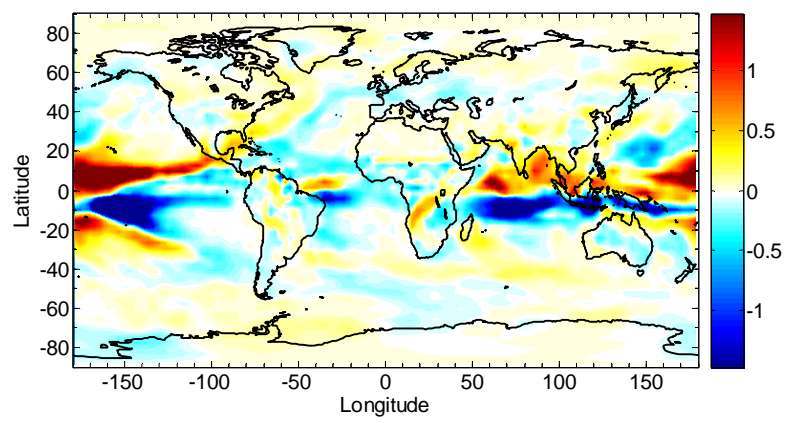

Fig. 5. (a) Changes in precipitation normalized anomalies between high and low BC terciles months (same as Fig. 1c but for global view); and (b) precipitation difference between the $\mathrm{BC}$ radiative forcing run and reference run (same as Fig. 4a but for a global view).

patterns are similar albeit different amplitudes, signaling the dominance of linear responses. In other regions, they are quite different, suggesting possible dominance of nonlinearity. The significance of such nonlinearity depends on the sensitivity of changes in tropical convective precipitation to the direct radiative effect of black carbon emitted from several major regions of the world (Wang, 2009). This aspect of aerosol effects on precipitation needs further investigations.

\section{Summary and discussion}

Using long-term satellite data and GCM simulations, we have demonstrated that aerosols from Africa significantly reduce convective precipitation in the WAM region owing (at least in part) to direct radiative forcing of black carbon. The reduction is particularly significant in boreal cold seasons when biomass burning smoke is prevailing. In both observations and simulations we found that associated with the reduction in precipitation are significant decreases in cloud amounts and cloud height, which suggest that the observed reduction in precipitation might be not directly caused by cloud microphysical effects of aerosol. The model simulations produced similar pattern of reduction only in convective (subgrid) precipitation, but not in large-scale (grid-resolving) precipitation. These all lead to the plausibility that the observed reduction in precipitation in the WAM region associated with increasing African aerosol is caused to a large extent by suppressed isolated (subgrid) convective precipitation due to direct radiative effect of black carbon, possibly from biomass burning in the region. It would be interesting to see how much the reduced precipitation by black carbon may vary when radiative effects of dust are also included in the model.

It is also of interest to discuss the relative significance of aerosol radiative effect to its microphysical effect on precipitation. As latest reported, when the aerosol optical depth (AOD) is higher than $\sim 0.25$, aerosol radiative effect becomes more significant over aerosol microphysical effect and tends to inhibit cloud amount (Koren et al., 2008), decrease convective available potential energy (CAPE), and thereby suppress precipitation (Rosenfeld et al., 2008). In the WAM region the aerosol optical depth is among the highest in the world with a climatological AOD mean of $\sim 0.4$ as we evaluated from 5-year (2003-2007) Aqua MODIS AOD. For all the calendar months, the climatological mean AOD are all higher than 0.25 except October which has an AOD mean of 
0.23. Moreover, showed for the precipitation change in South Asia from fully coupled coean-atmosphere global climate model experiments, the radiative forcing from aerosol-laden clouds can reduce surface evaporation, decrease meridional sea surface temperature gradient and increase atmospheric stability, and result in a precipitation reduction (Ramanathan et al., 2005). Therefore our attribution of cloud and precipitation suppression to aerosol radiative forcing agrees with these arguments and is in line with our current understanding of aerosol effects on precipitation.

Although we did not observe significant large-scale coherent relationship between aerosol and precipitation in boreal summer when dust are prevailing, we cannot rule out dust effect on precipitation completely from observations. Larger dust particles may act as effective aerosol savengers sweeping up the fine particles, and the aggregate dust-smoke mixtures are effective in absorbing solar radiation than by either dust or smoke alone, thus lead to stronger radiative forcing in the climate system (Ramanathan et al., 2001). More evidence also indicated that up to $30 \%$ of the observed precipitation reduction in the Sahel can be explained by the direct radiative forcing of the increased North African dust, as simulated from a global climate model (Yoshioka et al., 2005), and the main effect of the dust radiative forcing is to reduce precipitation over the Sahel region (Miller and Tegen, 1998; Konare et al., 2008). Cloud amount in thin low altitude clouds and ice phase clouds are reduced due to dust (Mahowald and Kiehl, 2003) while some other studies also reported that mineral dust causes reduction in precipitation (Kaufman et al., 2005; Rosenfeld et al., 2001). Nonetheless it appeals for more model simulations with aerosol radiative and microphysical effects from both dust and smoke, to advance our knowing on aerosol-cloud-precipitation interaction.

Because biomass burning is a major source of black carbon in the WAM region, our results suggest that to a certain extents the human-induced biomass burning may impact on local weather and regional climate. It calls for more systematic investigations on the biomass burning effect on global precipitation to reduce the uncertainty in evaluating the anthropogenic climatic impact and to improve our understanding on the human-earth interaction.

Acknowledgements. We thank the following data centres for data provisions: The Goddard Space Flight Center of NASA (http: //toms.gsfc.nasa.gov) for the monthly version 8 TOMS AI; the National Climate Data Center (NCDC) of NOAA (http://lwf.ncdc. noaa.gov) for the monthly GPCP version 2 precipitation data. NCEP Reanalysis 2 data provided by the NOAA/OAR/ESRL PSD, Boulder, Colorado, USA, from their Web site at http: //www.cdc.noaa.gov/. Interpolated OLR data provided by the NOAA/OAR/ESRL PSD, Boulder, Colorado, USA, from their Web site at http://www.cdc.noaa.gov/.

We are grateful to four anonymous reviewers whose valuable comments helped greatly to improve the paper. We acknowledge support by the NASA Grant: NNX06AF30G - Global Environmen- tal Change-Hazards and Regional Impacts, and support by the technical officers Don Anderson and Lucia Tsaoussi. This study was supported by NOAA's Office of Global Programs through awards under Cooperative Agreement \#NA17RJ1226 to CIMAS and by NASA through Grant NNX07ADI49G to MIT.

Topical Editor F. D'Andrea thanks four anonymous referees for their help in evaluating this paper.

\section{References}

Ackerman, A. S., Toon, O. B., Stevens, D. E., Heymsfield, A. J., Ramanathan, V., and Welton, E. J.: Reduction of tropical cloudiness by soot, Science, 288, 1042-1047, 2000.

Albrecht, B.: Aerosols, cloud microphysics, and fractional cloudiness, Science, 245, 1227-1230, 1989.

Briegleb, B. P.: Delta-Eddington approximation for solar radiation in the NCAR Community Climate Model, J. Geophys. Res., 97, 7603-7612, 1992.

Carlson, T. N. and Prospero, J. M.: The large-scale movement of Saharan air outbreaks over the northern equatorial Atlantic, J. Appl. Meteor., 11, 283-297, 1972.

Chiapello, I., Moulin, C., and Prospero, J. M.: Understanding the long-term variability of African dust transport across the Atlantic as recorded in both Barbados surface concentrations and large-scale Total Ozone Mapping Spectrometer (TOMS) optical thickness, J. Geophys. Res., 110, D18S10, doi:10.1029/2004JD005132, 2005.

Chung, S. H. and Seinfeld, J. H.: Climate response of direct radiative forcing of anthropogenic black carbon, J. Geophys. Res., 110, D11102, doi:10.1029/2004JD005441, 2005.

Denman, K. L., Brasseur, G., Chidthaisong, A., Ciais, P., Cox, P. M., Dickinson, R. E., Hauglustaine, D., Heinze, C., Holland, E., Jacob, D., Lohmann, U., Ramachandran, S., da Silva Dias, P. L., Wofsyl, S. C., and Zhang, X.: Couplings Between Changes in the Climate System and Biogeochemistry, in: Climate Change 2007: The Physical Science Basis, Contribution of Working Group I to the Fourth Assessment Report of the Intergovernmental Panel on Climate Change, edited by: Solomon, S., Qin, D., Manning, M., Chen, Z., Marquis, M., Averyt, K. B., Tignor, M., and Miller, H. L., Cambridge University Press, Cambridge, United Kingdom and New York, NY, USA, 2007.

Duncan, B. N., Martin, R. V., Staudt, A. C., Yevich, R., and Logan, J. A.: Interannual and seasonal variability of biomass burning emissions constrained by satellite observations, J. Geophys. Res., 108, 4100, doi:10.1029/2002JD002378, 2003.

Dwyer, E., Pinnock, S., Gregoire, J. M., and Pereira, J. M. C.: Global spatial and temporal distribution of vegetation fire as determined from satellite observations, Int. J. Rem. Sens., 21, 1289-1302, 2000.

Feingold, G., Jiang, H., and Harrington, J. Y.: On smoke suppression of clouds in Amazonia, Geophys. Res. Lett., 32, L02804, doi:10.1029/2004GL021369, 2005.

Forster, P., Ramaswamy, V., Artaxo, P., Berntsen, T., Betts, R., Fahey, D. W., Haywood, J., Lean, J., Lowe, D. C., Myhre, G., Nganga, J., Prinn, R., Raga, G., Schulz, M., and Van Dorland, R.: Changes in Atmospheric Constituents and in Radiative Forcing. In Climate Change 2007: The Physical Science Basis, Contribution of Working Group I to the Fourth Assessment Report of the Intergovernmental Panel on Climate Change, edited by: 
Solomon, S., Qin, D., Manning, M., Chen, Z., Marquis, M., Averyt, K. B., Tignor, M., and Miller, H. L., Cambridge University Press, Cambridge, United Kingdom and New York, NY, USA, 2007.

Kanamitsu, M., Ebisuzaki, W., Woollen, J., Yang, S. K., Hnilo, J. J., Fiorino, M., and Potter, G. L.: NCEP-DOE AMIP-II Reanalysis (R-2), B. Atmos. Meteorol. Soc., 83, 1631-1643, 2002.

Kaufman, Y. J., Koren, I., Remer, L. A., Rosenfeld, D., and Rudich, Y.: The effect of smoke, dust and pollution aerosol on shallow cloud development over the Atlantic ocean, Proceedings of the National Academy of Sciences, 102, 11207-11212, 2005.

Kiehl, J. T. and Brieglebm B. P.: The relative roles of sulfate aerosols and greenhouse gases in climate forcing, Science, 260, 311-314, 1993.

Konare, A., Zakey, A. S., Solmon, F., Giorgi, F., Rauscher, S., Ibrah, S., and Bi, X.: A regional climate modeling study of the effect of desert dust on the West African monsoon, J. Geophys. Res., 113, D12206, doi:10.1029/2007JD009322, 2008.

Koren, I., Kaufman, Y. J., Rosenfeld, D., Remer, L. A., and Rudich, Y.: Aerosol invigoration and restructuring of Atlantic convective clouds, Geophys. Res. Lett., 32, L14828, doi:10.1029/2005GL023187, 2005.

Koren, I., Martins, J. V., Remer, L. A., and Afargan, H.: Smoke Invigoration Versus Inhibition of Clouds over the Amazon, Science, 321, 946, doi:10.1126/science.1159185, 2008.

Ginoux, P., Prospero, J. M., Torres, O., and Chin, M.: Long-term simulation of dust distribution with the GOCART model: correlation with the North Atlantic Oscillation, Environ. Model. Softw., 19, 113-128, 2004.

Hansen, J., Sato, M., Ruedy, R., Lacis, A., and Oinas, V.: Global warming in the twenty-first century: An alternative scenario, Proc. Natl. Acad. Sci. USA, 97, 9875-9880, 1998.

Haywood, J. and Boucher, O.: Estimates of the direct and indirect radiative forcing due to tropospheric aerosols: A review, Rev. Geophys., 38, 513-543, doi:10.1029/1999RG000078, 2000.

Herman, J. R., Bhartia, P. K., Torres, O., Hsu, C., Seftor, C., and Celarier, E.: Global distribution of UV-absorbing aerosols from Nimbus 7/TOMS Data, J. Geophys. Res., 102, 16911-16922, 1997.

Huang, J., Zhang, C., and Prospero, J. M.: Large-scale effects of aerosols on Precipitation in the West African Monsoon region, Q. J. Roy. Meteorol. Soc., 135, 581-594, 2009a.

Huang, J., Zhang, C., and Prospero, J. M.: African aerosol and large-scale precipitation variability over West Africa, Environ. Res. Lett., 4, 015006, doi:10.1088/1748-9326/4/1/015006, 2009b.

Huang, J., Zhang, C., and Prospero, J. M.: Aerosol-Induced LargeScale Variability in Precipitation over the Tropical Atlantic, J. Climate, 22, 4970-4988, 2009c.

Huang, J., Zhang, C., and Prospero, J. M.: African Dust Outbreaks: A Satellite Perspective of Temporal and Spatial Variability over the Tropical Atlantic Ocean, J. Geophys. Res., doi:10.1029/2009JD012516, in press, 2009d.

Huffman, G. J., Adler, R. F., Arkin, P., Chang, A., Ferraro, R. Gruber, A., Janowiak, J., McNab, A., Rudolf, B., and Schneider, U.: The Global Precipitation Climatology Project (GPCP) Combined Precipitation Dataset, B. Am. Meteorol. Soc., 78, 5-20, 1997.

Hurrell, J. M.: Decadal trends in the North Atlantic Oscillation regional temperatures and precipitation, Science, 269, 676-679,
1995.

Ito, A. and Penner, J. E.: Historical emissions of carbonaceous aerosols from biomass and fossil fuel burning for the period 1870-2000, Global Biogeochem. Cycles., 19, GB2028, doi:10.1029/2004GB002374, 2005.

Lau, K. M., Ramanathan, V., Wu, G. X., Li, Z., Tsay, S. C., Hsu, C., Sikka, R., Holben, B., Lu, D., Tartari, G., Chin, M., Koudelova, P., Chen, H., Ma, Y., Huang, J., Taniguchi, K., and Zhang, R.: The Joint Aerosol-Monsoon Experiment: A New Challenge for Monsoon Climate Research, B. Am. Meteorol. Soc., 89, 369383, 2008.

Liebmann, B. and Smith, C. A.: Description of a Complete (Interpolated) Outgoing Longwave Radiation Dataset, B. Am. Meteorol. Soc., 77, 1275-1277, 1996.

Liu, X., Penner, J. E., and Wang, M.: Influence of Anthropogenic Sulfate and Black Carbon on Upper Tropospheric Clouds in the NCAR CAM3 Model Coupled to the IMPACT Global Aerosol Model, J. Geophys. Res., 114, D03204, doi:10.1029/2008JD010492, 2009.

Lohmann, U. and Feichter, J.: Global indirect aerosol effects: a review, Atmos. Chem. Phys., 5, 715-737, 2005, http://www.atmos-chem-phys.net/5/715/2005/.

Mahowald, N. M. and Kiehl, L. M.: Mineral aerosol and cloud interactions, Geophys. Res. Lett., 31, 1475, doi:10.1029/2002GL016762, 2003.

Menon, S.: Current uncertainties in assessing aerosol effects on climate, Ann. Rev. Environ. Resour., 29, 1-30, 2004.

Miller, R. L. and Tegen, I.: Climate Response to Soil Dust Aerosols, J. Climate, 11, 3247-3267, 1998.

Philander, S. G. H.: El Niño, La Niña and the Southern Oscillation, Academic Press, San Diego, CA, USA, 1990.

Prospero, J. M. and Lamb, J. P.: African droughts and dust transport to the Caribbean: climate change and implications, Science, 302, 1024-1027, 2003.

Ramanathan, V., Crutzen, P. J., Kiehl, J. T., and Rosenfeld, D.: Aerosols, climate, and the hydrological cycle, Science, 294, 2119-2124, 2001.

Ramanathan, V., Chung, C., Kim, D., Bettge, T., Buja, L., Kiehl, J. T., Washington, W. M., Fu, Q., Sikka, D. R., and Wild, M.: Atmospheric brown clouds: Impact on South Asian climate and hydrologic cycle, Proc. Natl. Acad. Sci. USA, 102, 5326-5333, 2005.

Roberts, D. L. and Jones, A.: Climate sensitivity to black carbon aerosol from fossil fuel combustion, J. Geophys. Res., 109, D16202, doi:10.1029/2004JD004676, 2004.

Rosenfeld, D., Lohmann, U., Raga, G. B., O’Dowd, C. D., Kulmala, M., Fuzzi, S., Reissell, A., and Andreae, M. O.: Flood or Drought: How Do Aerosols Affect Precipitation?, Science, 321, 1309-1313, 2008.

Rosenfeld, D., Rudich, Y., and Lahav, R.: Desert dust suppressing precipitation - a possible desertification feedback loop, Proc. Natl. Acad. Sci., 98, 5975-5980, 2001.

Rossow, W. and Schiffer, R.: ISCCP cloud data products, B. Am. Meteorol. Soc., 72, 2-20, 1991.

Rossow, W. and Schiffer, R.: Advances in understanding clouds from ISCCP, B. Am. Meteorol. Soc., 80, 2261-2287, 1999.

Rotstayn, L. D., Cai, W. J., Dix, M. R., Farquhar, G. D., Feng, Y., Ginoux, P., Herzog, M., Ito, A., Penner, J. E., Roderick, M. L., and Wang, M.: Have Australian rainfall and cloudiness increased 
due to the remote effects of Asian anthropogenic aerosols?, J. Geophys. Res., 112(D9), D09202, doi:10.1029/2006JD007712, 2007.

Schulz, M., Textor, C., Kinne, S., Balkanski, Y., Bauer, S., Berntsen, T., Berglen, T., Boucher, O., Dentener, F., Guibert, S., Isaksen, I. S. A., Iversen, T., Koch, D., Kirkevåg, A., Liu, X., Montanaro, V., Myhre, G., Penner, J. E., Pitari, G., Reddy, S., Seland, Ø., Stier, P., and Takemura, T.: Radiative forcing by aerosols as derived from the AeroCom present-day and pre-industrial simulations, Atmos. Chem. Phys., 6, 5225-5246, 2006,

http://www.atmos-chem-phys.net/6/5225/2006/.

Servain, J.: Simple climate indices for the tropical Atlantic Ocean and some applications, J. Geophys. Res., 96, 15137-15146, 1991.

Takemura, T., Nozawa, T., Emori, S., Nakajima, T. Y., and Nakajima, T.: Simulation of climate response to aerosol direct and indirect effects with aerosol transport-radiation model, J. Geophys. Res., 110, D02202, doi:10.1029/2004JD005029, 2005.

Tao, W. K., Li, X., Khain, A., Matsui, T., Lang, S., and Simpson, J.: Role of atmospheric aerosol concentration on deep convective precipitation: Cloud-resolving model simulations, J. Geophys. Res., 112, D24S18, doi:10.1029/2007JD008728, 2007.

Torres, O., Bhartia, P. K., Herman, J. R., Ahmad, Z., and Gleason, J.: Derivation of aerosol properties from satellite measurements of backscattered ultraviolet radiation: theoretical basis, J. Geophys. Res., 103(D14), 17099-17110, 1998.

Twomey, S., Davidson, K. A., and Seton, K. J.: Results of five years' observations of cloud nucleus concentration at Robertson, New South Wales, J. Atmos. Sci., 35, 650-656, 1978.
Wang, C.: A modeling study on the climate impacts of black carbon aerosols, J. Geophys. Res., 109, D03106, doi:10.1029/2003JD004084, 2004.

Wang, C.: Impact of direct radiative forcing of black carbon aerosols on tropical convective precipitation, Geophys. Res. Lett., 34, L05709, doi:10.1029/2006GL028416, 2007.

Wang, C.: The sensitivity of tropical convective precipitation to the direct radiative forcings of black carbon aerosols emitted from major regions, Ann. Geophys., 27, 3705-3711, 2009, http://www.ann-geophys.net/27/3705/2009/.

Washington, R. and Todd, M. C.: Atmospheric controls on mineral dust emission from the Bodélé Depression, Chad: The role of the Low Level Jet, Geophys. Res. Lett., 32, L17701, doi:10.1029/2005GL023597, 2005.

Washington, R., Todd, M. C., Engelstaedter, S., Mbainayel, S., and Mitchell, F.: Dust and the low-level circulation over the Bodele Depression, Chad: Observations from BoDEx 2005., J. Geophys. Res., 111, D03201, doi:10.1029/2005JD006502, 2006.

Xie, S. P. and Carton, J.: Tropical Atlantic variability: Patterns, mechanisms, and impacts. Earth Climate: The OceanAtmosphere Interaction, Geophys. Monogr., 147, 121-142, 2004.

Yoshioka, M., Mahowald, N., Conley, A., Collins, W., Fillmore, D., Zender, C., and Coleman, D.: Impact of Desert Dust Radiative Forcing on Sahel Precipitation: Relative importance of dust compared to sea surface temperature variations, vegetation changes and greenhouse gas warming, J. Climate, 20, 1445-1467, 2005.

Zebiak, S. E.: Air-sea interaction in the equatorial Atlantic region, J. Climate, 6, 1567-1586, 1993. 